\section{France and US explain failures}

AfTER third-stage ignition failures which destroyed two of the last three launches, the European space rocket Ariane looks set to go back to the makers for six months. The independent commission of inquiry which reported in Paris last week attributed Ariane's latest problems, and uncertain ignitions and failures early in the programme, to the small size of the "pyrotechnic" that lights the engine.

This view appears to counter speculation in the Los Angeles Times earlier this week that senior French sources believed Ariane had been sabotaged, but Jacqueline Schenkel of the Arianespace Washington office would say this week only that sabotage "had been practically ruled out". Certain questions are in fact "still being investigated" she said.

Ariane's third-stage, liquid hydrogenoxygen engine is ignited by a four-second pyrotechnic burning in the combustion chamber. But sometimes the fuel has failed to ignite; at others it has back-fired and gone out or faltered but continued. Ignition has proved to be sensitive to too many factors. The tolerances of the process have to be broadened, the commissioin says, and the easy solution is a bigger pyrotechnic.

This will take approximately six months, but in the face of similar launch difficulties in the United States with the shuttle and conventional rockets, Arianespace is still enjoying a burgeoning order book. Orders for 36 satellites to be placed in orbit at a net cost of some $£ 1,000$ million are still in hand, the company says.

Meanwhile, in Washington, explanations for US rocket failures abounded last week. At the Pentagon, the Air Force explained why its Titan 34D booster exploded seconds after lift-off. Over at the National Aeronautics and Space Administration (NASA), an investigation revealed faulty wiring as the cause of the failure of a Delta rocket on 3 May. Neither investigation showed fundamental flaws in rocket design, and launches could resume as soon as new prelaunch procedures can be implemented.

The Titan's problems started when rubber insulation apparently pulled away from the steel wall of the solid rocket motor (SRM) shortly after lift-off. This allowed combustion products to reach the booster wall, weakening it to the extent that it could no longer withstand the pressures inside the booster. Approximately 9 seconds after SRM ignition, the rocket exploded, causing $\$ 70$ million damage to the launch pad and adjacent facilities.

The Titan 34D SRMs are similar in design to those used on the space shuttle, but have a different manufacturer - United Technologies rather than Morton Thio- $\mathrm{kol}$. The commission investigating last January's shuttle disaster concluded that a failute of the O-ring seals caused the Challenger accident. But General Nathan Lindsay, who headed the Air Force investigation, said the $\mathrm{O}$-ring seals joining the solid rocket segments "did not contribute to the [Titan 34D] mishap".

Lindsay does not believe that the accident represents a flaw in the SRM design. He pointed out that 940 booster segments have launched successfully without a problem. The Air Force plans to upgrade its inspection procedures of the solid rocket motor segments, but otherwise is

\section{Nature conservation}

IN a country as stripped bare of woodland as Britain, it might seem certain that the planting of new forests would be universally welcomed. But last week, all the nation's major voluntary conservation bodies

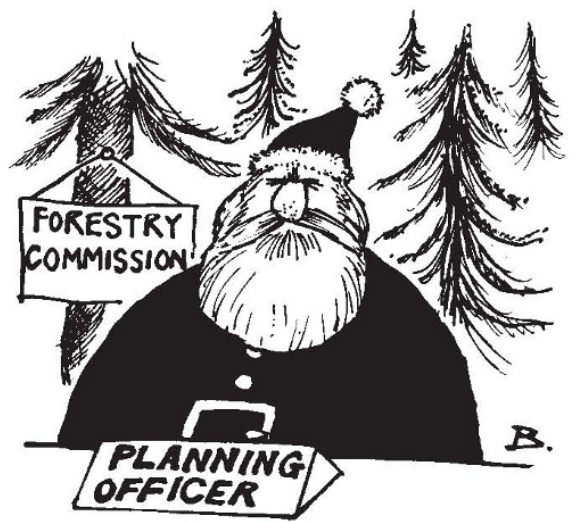

joined hands in a report protesting against the rapid growth of Britain's forests.

The report comes from Wildlife Link, which represents 24 conservation organizations with a total membership of $1.4 \mathrm{mil}$ lion. It is not more trees that they find objectionable but that present government policy, grants and tax relief favour a type of forest practice which they believe is damaging to the environment. The pace of planting has certainly increased: nearly 5.5 million acres of new forest a year, double that of fifty years ago. And, says the report, much of that is in massive monocultures, usually of Sitka spruce, that are transforming open land habitats and destroying the flora and fauna of moorland, heath, bog and sand dune. Two and a half million acres have gone since 1919. Vast areas of Scotland are now "tree farms" which destroy wildlife and are utterly different from any native forest that might once have grown there.

The critique by the conservation organizations comes a week after the publi-

making no major alterations in the Titan $34 \mathrm{D}$ as a result of the accident. Lindsay expects that Titan 34D flights will resume within a year.

The problems of the Delta rocket were primarily electrical, according to NASA's investigation. A short in the main engine control circuits caused both the main and altitude engines to shut down. Without controlling thrust from the engines, the Delta broke apart in the atmosphere and was destroyed by ground controllers. Vibration at lift-off apparently caused the erosion of some insulation in a wiring harness, leading to the short circuit. NASA's investigation board recommended redesign of parts of a wiring harness, as well as increased attention to detail in construction. Robert Walgate \& Joseph Palca

\title{
Too many of the wrong trees?
}

cation by the Nature Conservancy Council of Nature conservation and afforestation in Britain, which details the increasing conflict between forestry interests and conservation needs. Each of the arguments for further massive plantations - that there is still plenty of open land left; that, as much of what is now open land was once forest, afforestation is a return to a more natural environment; and that forests support more wildlife than open ground - is examined and found wanting. Nor does the report find economic arguments compelling. Although Britain imports 90 per cent of its timber so that the need for increased domestic production would seem vital, forestry gives a low return on capital invested and takes up funds that might be better spent elsewhere.

The conservation bodies would like to see more sensitive planting, particularly using native tree species, in a manner that would help to increase the diversity of wildlife and avoid damage to unique open habitats. Various possible new planning control methods are suggested, but the first task remains to notify all Sites of Special Scientific Interest (SSSI) and to ensure that they are adequately protected. One possibility might be a stronger regulatory role for the Forestry Commission which processes applications for forestry grants. But the commission would first have to strike a better balance between timber production and protection of the environment in its own activities.

In the longer run, new and more attractive forestry schemes may appear. There is pressure within the European Community to reduce excess food production by converting relatively fertile farmland to forests. These lowland forests could be of native hardwoods and support rich wildlife communities; quite different from the massive forests being grown on the northwestern moorlands.

Alun Anderson 